\title{
Unamuno Frente a la Poesía de Rubén Darío
}

En I896, con la publicación en Buenos Aires de las Prosas profanas de Rubén Darío, libro que en sí define, fija y promueve el modernismo, llega a su plenitud esta nueva escuela literaria. Hay que fijarse bien en esta fecha - I896- porque es en estos mismos años cuando Unamuno, cautivado por lo gauchesco argentino, empieza, en serio ya, a estudiar y comentar públicamente cuanta producción literaria le llega de América. No se debe olvidar tampoco que los años de más intenso interés unamuniano por la literatura hispanoamericana son los mismos en que el modernismo se adopta como expresión 'casi exclusiva en el ambiente literatio hispánico. $\mathrm{Y}$ cuando se considera que el modernismo tiene raíces francesas y que todos los jóvenes intelectuales vuelven sus miras hacia "La cité lumière", se comprenderá por qué don Miguel se pasó la vida gritando, a veces con razón y otras sin ella, contra las nuevas formas literarias. En casi todo lo que escribió en estos años se ve que iba buscando siempre la oportunidad de criticar, ora con agudeza, ora con acidez, censurar $\mathrm{y}$. hasta increpar a los seguidores todos, buenos y malos, de Verlaine, Rimbaud, Baudelaire, Mallarmé, Leconte de Lisle, Remy de Gourmont, etc. Y en su afán de atacar, de atacar siempre, se comprende también el que haya ensalzado a otros escritores que, a decir verdad, no cuentan con otro mérito que el de no haber seguido preceptos modernistas. En esto, el "misogalismo" de que sufría don Miguel lo llevaba muy lejos, haciéndole criticar injusta e indebidamente a un escritor de la talla de Rubén Darío, o, al otro extremo, ensalzar a escritores de bajo nivel artístico como, por ejemplo, el uruguayo Alberto Nin Frías. Y esto lo hace don Miguel de Unamuno, el mismo Unamuno que en varios lugares expresó que él también había aprendido y tomado mucho de la 
literatura francesa. Por ejemplo, en una carta firmada en agosto de 1905 y dirigida desde Salamanca a su buen amigo francés, el hispanista Camille Pitollet, exclama: "Yo, que debo mucho a la literatura francesa, muchísimo, y que tengo amigos franceses tan amigos como usted, padezco, he de confesarlo, un misogalismo crónico. Solté a tiempo los andadores de la literatura francesa a que tanto debo."' Seguramente, al escribir cstas líneas, pensaba don Miguel en escritores como Balzac, Stendhal, Sainte. Beuve, Flaubert y, especialmente, Senancour, el autor francés que leía con más entusiasmo y con quien más se identificaba. A todos ellos rindió Unamuno sincero homenaje en muchos artículos, alabándoles siempre como valores castizamente franceses. Se comprenderá entonces que el hablar de "misogalismo" no argumenta que no le haya complacido la producción literaria francesa y que no hubiera apacentado su espiritu en obras francesas también; lo que indica este término es cierta desconfianza del carácter francés y acaso cierto temor de que el excesivo culto francés acabe con lo castizo hispánico. El leer, gustar y tomar instrucción de la literatura francesa, y hasta dejarse influir por ella, es en sí laudable; pero, cuando esa admiración se convierte en ciega subyugación y única fuente de inspiración, uno no puede menos que dudar de su valía. Y lo que veía don Miguel en los jóvenes decadentistas hispanoamericanos era que idolatraban sin reservas $y$-creo que esto toca en lo vivo del problema- a despecho de valores y bellezas nacionales hispánicas, a París, sin que París les hiciese caso alguno, tratándoles fría, desdeñosa y condescendientemente. El modernismo iba rebajando, mejor destrozando, el carácter nacional, americano, hispánico de la literatura hispanoamericana y, por lo tanto, Unamuno tenía razón al quejarse continuamente. Porque fue una queja que se puede trazar desde sus primeros artículos de fines del siglo pasado hasta los últimos que escribió. Pero, aunque su queja tenía una base justa, el mucho gritar y censurar le dañaba su sentido crítico e impedía que se acercara serena y objetivamente a algunos — son una muy reducida minoría- escritores modernistas. Tal con Rubén Darío, poeta en quien se cifra todo el movimiento literario y de quien se puede decir que nunca entendió don Miguel.

Las relaciones literarias y personales entre el vasco y el nicaragüense empezaron turbias, y así habían de quedar hasta la mucrte de éste en I9I6. Se conocieron en Madrid en I899, durante la segunda visita de Rubén a España. En su Autobiografia Datío nos cuenta ese encuentro:

1 Camille Pitollet, "De mis memorias", Boletín de la Biblioteca Menéndez y Paldyo, XXVIII, Núms. 1 y 2 (1952), pág. 69. 
Me presentaron una tarde como a un ser raro - es genial' y 'no usa corbata' me decían-, a don Miguel de Unamuno, a quien no le agradaba, ya en aquel tiempo, que le llamaran el sabio profesor de la Universidad de Sala. manca. Cultivaba un sostenido tema de antifrancesismo. $Y$ era indudable. mente un notable vasco original. ${ }^{2}$

Y Unamuno en un artículo escrito a la muerte de Darío, comenta este encuentro en la manera siguiente:

Aunque nos vimos y conversamos y paseamos juntos media docena de veces, había algo que nos mantenía apartados, aun estando juntos... Yo debía parecerle a él duro y hosco; él me parecía a mí sobrado comprensivo... Nos veíamos, nos hablábamos, nos apreciábamos mutuamente, pero ni uno ni otro se decidía a romper esa muralla. ${ }^{3}$

Como dan a entender las palabras de ambos poetas, el recelo y la desconfianza caracterizaban las pocas veces que se vieron personalmente, $y$ eso a pesar de escribirse y tratarse amistosa, aunque reservadamente, a pesar de comprender y en parte aplaudir sus obras respectivas, a pesar de que fue Darío mismo quien dio acceso a Unamuno a la prestigiosa tribuna hispanoamericana en la cual iba a publicar centenares de artículos, el diario bonaerense La Nación, y también uno de los primeros que reconoció alto valor lírico en las poesías del vasco. No se veían porque no querían verse: así se pueden resumir sus largas y tempestuosas relaciones. No nos vamos a poner aquí a estudiar sus tratos personales, porque el meternos en este tema, por mucho que nos sintamos atraídos a ello, nos llevaría a otros campos, y acaso a otro artículo. Sin embargo, nos referiremos a ellos - ¡claro está! - en cuanto nos ayuden a aclarar o establecer juicios unamunianos sobre la poética rubeniana. Pero el estudiar sus relaciones personales sólo por estudiarlas no creemos que añada nada nuevo a la visión y los juicios que tenía don Miguel sobre el modernismo en general - Darío en particular. Más bien son resultado de esa visión que causa de ella y, como tal resultado, no creemos que venga a propósito en nuestro trabajo. Vamos, pues, a las declaraciones de Unamuno sobre el vate nicaragüense."4

2 Rubén Darío, Autobiografia, Vol. XV, Obras Completas (Madrid, 1918), pág. 173 .

3 "De la correspondencia de Rubén Dario", La Nación de Buenos Aires (10 mayo 1916).

if El que quiera seguir con este tema debe referirse a los estudios de Manuel García Blanco, "Rubén y Unamuno", Cultura Universitaria, Núm. XLIII (mayojunio, 1954), págs. 15-28; José Luis Cano, "Rubén y Unamuno", Clavileño, IV, 
El tiroteo entre Dario y Unamuno fue empezado por éste en un artículo sobre La maldonada de Francisco Grandmontagne; en él Unamuno discurría sobre el estado de la literatura argentina en particular y la americana en general, pero sobre todo dejaba sentado que se oponía totalmente al afrancesamiento que por entonces caracterizaba las letras hispanoamericanas. Estas declaraciones hirieron la sensibilidad de Rubén, y de inmediato - su artículo de combate está firmado el mismo día en que salió el de Unamuno- se puso a defender públicamente el afrancesamiento americano en un artículo titulado "La Pardo Bazán en París. Un artículo de Unamuno", publicado en la revista madrileña Vida Nueva. Defendiéndose ingeniosa y eruditamente a la vez, dice:

Crea el señor Unamuno que mis Prosas profanas, pongo por caso, no hacen ningún daño a la literatura científica de Ramos Mejía, de Coni o a la producción regional de J. V. González, ni las maravillosas Montañas de Oro de nuestro gran Leopoldo Lugones perturban la interesante labor criolla de Leguizamón y otros aficionados a ese ramo que ya ha entrado en verdad en dependencia folklórica. Que habrá luego una literatura de cimiento crio. 1lo, no lo dudo; buena muestra dan el hermoso y vigoroso libro de Roberto Payró La Australia Argentina y las obras del popularísimo e interesante 'Fray Mocho'5

Leído el artículo de Rubén, Unamuno le escribe, agradeciéndole su artículo y dándole las gracias "por la afectuosa consideración con que me trata. Sobre tales bases es imposible no venir a un acuerdo". En esta manera, pues, se traba la amistad epistolar entre Darío y Unamuno, y se le despierta el interés de éste por leer más poesías suyas. Y en esta misma carta tenemos una de las primeras valoraciones de Unamuno sobre la poesía de Darío: Hela aquí:

Lo que yo veo, precisamente en usted, es un escritor que quiere decir, en

núm. 23 (septiembre-octubre, 1953), págs. 18-22; Jerónimo Mallo, "Las relaciones personales y literarias entre Darío y Unamuno", Revista Iberoamericana, IX, núms. 17 y 18 (febrero y mayo, 1945), págs. 61-72; José Luis Martín, "Unamuno y Dario: Dos angustias en una", Alma Latina, núm. 832 (1951), págs. 17-18; y Delfina Molina y Vedia de Bastianini, "Rubén Darío y Unamuno", La Nación de Buenos Aires (11 abril 1948).

Respecto al epistolario cambiado entre los dos poetas, véase: Alberto Ghiraldo, Arcbivo de Rubén Dario (Buenos Aires, 1943); Epistolario de Rubén Dario, edición y estudio preliminar de Ventura García Calderón (París, 1920); también, se incluye una carta inédita en el estudio ya citado de García Blanco.

5 El artículo fue recogido por Rubén en su España contemporánea, Vol. XIX. Obras completas (Madrid, 1922), y ahí se puede leer en su totalidad en las páginas 116-118. 
castellano, cosas que ni en castellano se kan pensado nunca ni pueden boy en él pensarse. Tiene usted que hacerse su lengua. ${ }^{6}$

Sin embargo, en marzo de este mismo año, antes de cscribir su artículo sobre La maldonada, antes de conocer personalmente a Rubén, y antes de que Rubén escribiera sobre él, ya conocía su obra poética y ya se interesaba por ella, tanto que, en carta a Luis Ruiz Contreras, fechada el I5 de dicho mes, habla con simpatía de los versos del nicaragüense y hasta le pide a aquél que le mande la dirección de Dario para poder ponerse en contacto directo con él. Su valoración de Darío es rápida y muy directa, casi telegráfica; dice que "es americano; siente con profundidad; piensa con altura, y aunque 'aparisiensado', conserva el buen sentido y el cuajo español que otros han perdido ya. Déme, pues, nota de su dirección". ${ }^{7}$ Como se ve, la primera impresión de la obra poética rubeniana, aunque sabemos de ella sólo fragmentariamente, es de agrado y parece indicar que cree a Dario destinado a ser gran poeta de la lengua, si se puede apartar de la que el maestro español consideraba nefasta influencia parisiense.

En esos mismos días -el 23 de abril de 1899 - se publicaba en la revista bonaerense $\mathrm{El}$ sol de domingo una carta abierta que había mandado don Miguel a Casimiro Muñoz y en la cual se leía esto: "Hace poco, leyendo unas quejas de Rubén Dario, porque París no hace caso a los literatos hispanoamericanos confundiéndoles con los rastaquouères, me dije que tienen razón en París." En esto se equivocaba don Miguel: primero, no era Darío el que había dicho eso, aunque había expresado este mismo sentimiento en una ocasión, sino el venezolano Pedro-Emilio Coll, y también, como le comunica Rubén en carta de I6-V-I899, él no se quejaba sino que celebraba "el desdén de París con nuestros mediocres y amo. jamados de América, hijos legítimos de una España que no es la que vale, la grande intelectualmente."' Indignado, le ruega Darío que rectifique su frase públicamente porque - y en esto tenía sobrada razón, dado el ca. rácter de los literatos hispanos de entonces- podía ser mal interpretada por algunos americanos y así podía resultar muy dañosa.

Y, efectivamente, así lo hizo don Miguel, mandándole antes de que se publicara un articulillo titulado "Rubén Dario juzgado por Unamuno.

6 Alberto Ghiraldo, obra cit., págs. 38-39.

7 Luis Ruiz Contreras, Memorias de un desmemoriado (Madrid, 1946), pág. 152.

8 Manuel García Blanco, artículo cit., pág. 17.

- Epistolario, pág. 33. 
Una rectificación", publicado en la misma revista el 8 de julio del mismo año. En la carta que acompaña al artículo, don Miguel - y por primera vez-, se dedica casi exclusivamente a hablar del afrancesamiento hispanoamericano y el porqué del disgusto que le causa:

Debo decirle que no acabo de comprender del todo esa atracción que sobre ustedes ejerce París, ni ese anhelo de que sea precisamente Paris, y no Londres, a Berlín, o Bruselas, o Estocolmo o... Heidelberg, donde los descubran. Que fuera Madrid lo comprenderia, porque, hoy por hoy, es el centro de los pueblos de lengua española, y por mucho que exageremos (yo el primero), nuestra incultura, al fin y al cabo en español escribimos, y los que piensan en español son los que, ante todo, han de nutrirse de la savia espiritual de nuestros escritores... En el inmenso coro del universo hay. sitio para todos, con tal de que cada cual dé su nota nativa, la que le es propia. Lo malo es que el ruiseñor pretenda rugir o gorjear el león.10

Esta observación, tan arraigadamente unamuniana, nos explica en gran parte su adversión por los afrancesados: hay que ser de su país y de su tiempo para ser de todos los países y de todos los tiempos. $Y$ esto es precisamente lo que temía en cuanto a Dario: París acabaría por dominarlo.

No obstante estas observaciones, Unamuno ya veía en él al poeta, al que vive sola y exclusivamente por y para la poesía. Y le felicita también por su afán de renovar la expresión poética española. Le dice, en carta de I6-IX-I899:

De usted me gusta mucho la seriedad, la verdadera seriedad, el esfuerzo pot renovarse de continuo. Usted es de los que estudian; se ve en sus trabajos. ¿A quién se le ha ocurrido aquí refrescar la vena de nuestro viejo Cancionero de Baena? Le felicito por ello. Es usted de los que aspitan a comprenderlo todo, de los de mente extensa y hospitalaria, que diría Coll.11

Desde el principio, pues, lo admiraba como poeta; pero, a la vez, lo regañaba por ser el propulsor del modernismo en el mundo de habla espa, ñola. Unamuno no podía - ya se ve- reconciliar una cosa con la otra. En esta nota tan agitada empiezan las relaciones, tanto personales como literarias, entre Darío y Unamuno, y en verdad, el que se muestra más cordial y más amigo siempre es el nicaragüense.

En 1900, escribe Unamuno su primer artículo para La Nación de Buenos Aires y lo dedica - no podría haberlo hecho de otra manera- a

(10 Alberto Ghiraldo, obra cit., págs. 41-42.

11 Citado por Jerónimo Mallo, artículo cit., pág. 68. 
Rubén. A pesar de que fue Darío - como dijimos-quien le dio acceso a dicho periódico, Unamuno, cegado por su propia campaña antigalicista, no supo agradecérselo debidamente. En otra carta a Ruiz Contreras, escrita pocos días después de publicarse el artículo, hasta llega a sospechar de su "amigo":

He recibido - escribe- de La Nación, de Buenos Aires, el cheque en nago de mi artículo; y siendo asi que Rubén Dario me dijo que me darían 125 pesetas, 'máximo de lo que pagan', según él, me han enviado 150 (que de seguro no es el máximo, ni mucho menos). ${ }^{12}$.

Si Unamuno escribió esto en la intimidad, jnos imaginamos el reojo y la falta de comprensión con que habría leído la poesia de Rubén! Parev ce que estaba empeñado en no aplaudirle en nada. Pero, en otra carta del mismo año, ésta dirigida a Candamo, vemos que esta negación del valor literario de Rubén se debe en parte a que Darío, a su vez, tampoco estaba muy dispuesto a aceptar la obra poética de Unamuno. Leemos: 'Rubén Darío dice de mis versos que son 'demasiado sólidos'; prefiero esto a que sean demasiado gaseosos, a la americana..."13 Los dos poetas habían llegado a un jaque mate mutuo literario; ni uno ni otro concedía que se pudiera haber equivocado.

En I90 I trata Unamuno de romper - aunque no se apura en elloesa muralla de hielo que los mantenía separados. En este año se publica la España contemporánea de Rubén, quien envía un ejemplar dedicado a Unamuno. El libro, como se sabe, se compone de artículos aparecidos en La Nación, y entre ellos se incluye el artículo de 1899 que rebatía las declaraciones unamunianas sobre la literatura afrancesada hispanoamericana. Algo inesperadamente, Unamuno alaba el libro, tanto en carta personal al autor como en artículo dirigido al gran público hispánico. En la carta en que le acusa recibo del libro, le dice Unamuno:

Hace unos días tecibí su interesantísimo libro, España contemporánea, de que conocía la mayor parte por haberla leído en La Nación. Ha hecho usted una obra meritoria, tanto para nosotros los españoles como para los americanos. Obras así labran más la fraternidad de castas que cuantos Congresos, como el último, se celebren..$^{114}$ De su irabajo he de ocuparme en La Lecturat ${ }^{15}$

12 Luis Ruiz Contreras, obra cit., pág. 172.

13 Manuel García Blanco, Don Miguel de Unamuno y sus Poesias (Salamanca, 1954), pág. 37.

14 Se refiere a los Congresos Iberoamericanos que se organizaban y desorganizaban en los primeros años de este siglo.

115 Alberto Ghiraldo, obva cit., pág. 119. 
Efectivamente, en noviembre del mismo año aparece en dicha re. vista la reseña prometida, y en ella se echa de ver el mismo tono apacible y amable de la carta que la anuncia. Lo esencial de la reseña destaca que el libro es "una viva causerte, llena de chispazos, algo así como un collar sin hilo, de notas echadas un poco al azar. Revélase en él un espíritu sensible abierto a todos los vientos y reflejando cuantos ecos le han herido; sus juicios, sin dejar de ser suyos y llevar su sello, se nos presentan como sintesis de juicios que flotan en el ambiente cultural madrileño. En cierto ambiente, se entiende. Leyendo este libro de Darío se ve lo que de nuestra España cree y juzga la juventud de la Corte madrileña." 116 El libro es, por lo tanto, algo caleidoscópico, pero nos presenta un cuadro ameno de la vida española. Sin embargo, no pierde la ocasión don Miguel de hablar también de su afrancesamiento, aunque... ¡lo defiende! YY es que por debajo de su capa francesa cree vislumbrar Unamuno el alma española de Rubén, así: "Se ha dicho de Darío que hasta cuando escribe en castellano correcto, corriente y moliente, parce traducido del francés, bien traducido, pero traducido al cabo. No lo creo así. Lo que hace es pensar en americano - aunque no lo crea nuestro amigo Rodó-, en genuino americano." 17 Lo cual quiere decir "español", puesto que en castellano escribe y en castellano piensa. Unamuno se ha dado cuenta del valor artístico de Rubén, del supremo artista que es. Y en este artícu. lo vemos que quería extenderse en una alabanza sentida y amistosa, pero ... no lo hace. $Y$ no lo hace porque su misogalismo no se lo permite, porque, a pesar de lo que pudiera haber dicho, seguía creyendo que Darío era en el fondo un afrancesado. Su crítica, entonces, viene a cobtar un cierto tono de sensatez, de punto medio, y no hace más que señalar su estilo y su visión artística, lo cual es, al fin y al cabo, la misión del crítico sensato, pero no la de Unamuno. Y nosotros preferimos éste a aquél. Dice:

Hay algo de inarticulado, de desgranado, de 'discreto' (el que a 'concreto' se opone), de invertebrado en el decir y exponer de Darío; más que línea seguida, sigue línea punteada. Lo he dicho al principio: es cinematográfico, hasta en el titular de las imágenes que se suceden. Difícilmente se ve el principio de continuidad bajo ellas. Las frases se suceden, sobre un mismo asunto, asociadas sin duda; pero no nacen unas de otras. Su estilo llega a ser palpitante... pero no es ondulante casi nunca. $Y$ así es su pen. samiento. Cuesta descubrir en éste la famosa corriente o flujo continuo de

16 "España contemporánea, por Rubén Dario", La Lectura (noviembre, 1901), pág. 119.

17 Ibidem. 
James; parece más bien un espejo que reproduce, transformándolas según su color y curvatura, las imágenes que ante él se suceden. $Y$ un espejo en mosaico. ${ }^{18}$

Pocas veces Unamuno llegó a tal objetividad fría en su crítica, y - dicho sea en honor suyo- lo hizo suprimiendo deseos o de gritar locamente contra su afrancesamiento o de ponerse en íntima comaraderia con él. En vez de esto, sigue Unamuno examinando, serena y reposada. mente, su libro, llegando por este camino a algunas conclusiones muy atinadas y muy justas:

Darío juzga, más que con doctrina, con un temperamento.. Y Y al juzgar, incorpora a su propio juicio, dése o no de ello cuenta, los juicios que en torno a sus oídos han revoloteado y que le sirven como de acordes del propio. De aquí que resultan con cierta complejidad armónica, hasta con intimas disonancias a las veces, nada unilaterales, ni mucho menos 'monótonos'.19

Hasta cuando le censura algo, lo hace amistosamente, y aunque sus propias ideas sean diametralmente opuestas a las del nicaragüense. Por ejemplo, al hablar de la urbanidad de Darío, característica que lo mantiene apartado de una honda comprensión del pueblo español y que no le permite penetrar en las raíces españolas, dice muy sencillamente:

Una cosa de España no ha visto apenas Darío, y es el campo; ni el campo mismo ni el pueblo que lo habita. El capítulo que le dedica, "Fiesta cam. pesina", es de lo más flojo del libro: vese en él que Darío, el enamorado de París y de Buenos Aires, y aun de Madrid, es esencialmente urbano.20

Una vez más ha dado en el clavo don Miguel, pero ni se excita ni hace alarde de ello. $\mathrm{Y}$ así es la reseña toda: llena de vislumbres y ob. servaciones muy atinadas, pero escrita con sensatez, equilibrio y derechura. Tal vez se deba esțe tono a que hasta ahora Rubén siempre lo ha tratado con respeto y con cierta simpatía aun cuando más se aparta de la doctrina unamuniana. Rubén fue siempre bueno con Unamuno, y ésta es una de las pocas veces en que éste reciprocó esa bondad.

El libro le había gustado de verdad y cuanto haya dejado escrito sobre él muestra agrado y simpatía. Por ejemplo, en una carta a Can. 
damo, fechada en ese año de I90I, sigue con el mismo tono de antes: aplausos y reservas a la vez:

Rubén Darío es algo digno de estudio; es el indio con vislumbres de la más alta civilización, de algo esplendente y magnífico, que al querer expresar lo inexpresable balbuce. Tiene sueños gigantescos, ciclópeos; pero al des. pertar no le queda más que la vaga melodía de ondulantes reminiscencias. Tiene un valor positivo muy grande; pero carece de toda cultura que no sea exclusivamente literaria (éste es, a mi juicio, el mal mayor de nuestros literatos) ...21

Y en la misma carta se le ve este mismo tono de exaltación refrenada cuando habla específicamente de su España contemporáned:

El libro de Darío tiene bajo su benévola bonbomie un fondo de severidad; su efecto es miroitant. Me parece, por lo demás, un libro en que ha colaborado mucha gente; no siempre revela juicio propio. Pero es un bonito cinematógrafo (algo caleidoscópico) de nuestra España exterior, no de la intima ...22

¿Se ve ya ese tono de "Sí, pero no" en que están escritas estas críticas unamunianas? ¿No se ve también que Unamuno, a pesar de lo que dijera públicamente en otras ocasiones, comprendía-nosotros hasta creemos que en el fondo saboreaba - el arte literario de Rubén? Pero Rubén, ¡ay!, se iba dejando seducir por París y, lo que era peor aún, iba a ser una víctima más del boulevard, guiado ahí por el bulevardero por excelencia, el cronista sensual y mosqueteril, Gómez Carrillo. Así pensaba don Miguel en I90r.

En 1902, siguen escribiéndose los dos amigos, Darío poniendo a Unamuno al tanto de lo hispanoamericano y Unamuno empeñado en hacerse aceptar como poeta por Darío, que desde el principio se había mostrado algo hostil hacia la lira unamuniana. Esto seguramente desagradó a Unamuno - ya se sabe cuánto se ufanaba de llamarse poeta-y tal vez nos ayude a explicar en parte ese telón de hielo que se interponía a su amistad. En estos años, a Rubén se le iba considerando el primer poeta en lengua castellana; y Unamuno seguía pacientemente componien.

21 Ensayos, prólogo y notas de Bernardo G. de Candamo, Vol. II (Madrid, 1945), págs. $17-18$.

${ }_{22}^{2}$ Ibídem, pág. 18. Como se puede apreciar en esta cita y en otras, también Unamuno sabía emplear voces francesas en sus artículos críticos, aunque en la mayoría de los casos, lo hacía en plan irónico. 
do sus versos en Salamanca sin que se le prestase atención particular. Y Darío, el adorador de París, iba afrancesando, cada año más, el ambiente cultural hispánico, afrancesamiento que, según Unamuno, acabaría por ahogar a España. El gran público hacía más caso a la poética modernista del nicaragüense que a las protestas del vasco. Además, en las cartas de estos años, se ve una campaña sostenida por parte de Unamuno de hacer que Rubén acepte y aplauda su propia obra lírica, mandándole poemas, hablando de su propia poesía siempre que puede, pero - y esto es lo más curioso- nunca diciendo nada de la poesía de Rubén. En efecto, ¡ni había leído sus Prosas profanas! Y eso que hacía seis años que el tomo iba conquistando al mundo hispánico. Rubén, el afrancesado, se había he. cho un cause célèbre hispánico y a Unamuno le desagradaba y le dolía profundamente.

Pasan dos años en que ni se escriben ni vocean sus diferencias periodísticamente, dos años en que la fama de Dario se hace internacional. Sigue Unamuno tratando de convencer a Rubén de la valía lírica de sus versos, y en carta fechada el 3 de septiembre de I904 le habla de su famosa "Oda" a Salamanca, dejando ver entre líneas la aversión que sentía hacia París: "Véngase por acá-le ruega - véngase a ver y a sentir este soto de altas torres ... He corregido ayer una poesía - creo que la mejor que he hecho- - titulada 'Salamanca', y que aparecerá en La ilustración es. pañola y americana. Los versos son sáficos clásicos, cual cuadra a esta ciudad". Y a continuación viene a la defensa de su dorada y adorada Salamanca, a la que Rubén había dado el mote de "ciudadón dormido en el páramo", llamándola "el viejo castillo roquero espiritual de mi dorada Salamanca, lejos de la feria de las vanidades." 23

De esta carta en adelante, las relaciones entre el vasco castellanizado y el nicaragüense aparisiensado se van haciendo cada vez más acerbas y tiesas. Sin embargo, en su largo artículo "Algunas consideraciones sobre la literatura hispanoamericana", el que escribió a base del libro de Riva Agüero, Carácter de la literatura del perí ináependiente y que está firmado en noviembre de r905, al hablar de la sincronización de los movimientos literarios españoles y americanos y de la influencia que a veces ejercen éstos en aquéllos, trae a colación los versos de Darío, aunque a regañadientes :"Hoy mismo - dice- ¿cabe negar la influencia, buena o mala, mejor o peor, que de esto no nos toca hablar ahora, de Rubén Darío

23 M. Garcia Blanco, articulo cit., pág. 20. 
en la juventud española que al cultivo de la poesía se dedica?"24 Y en el mismo artículo, vuelve a entonar el tema que vimos antes al hablar de su España contempioránea, el de que tenía Rubén Darío, a pesar de su afrancesamiento, un alma y una expresión artística hispánicas:

¿Quién no sabe que, por debajo de su afrancesamiento, más aparente que real, Dario ha sido, y va cada vez más siendo, profundamente español? ¿Quién no sabe que ha ido a buscar fuerzas, para remozar sus formas líricas, en antiguos cantares españoles del mester de clerecia?25

No se puede negar que don Miguel había comprendido, aunque había leído poco de ella, la poesía de Dario hay un fondo de intima verdad en esto de que ya iba afirmándose cada vez más su alma hispánica. Buen ejemplo nos lo ofrecen sus Cantos de vida y esperanza, libro que, aunque no lo leyó Unamuno hasta I908, se estampó en este mismo año.

Pero el afrancesamiento pudo más que el carácter esencialmente hispánico en cuanto a la crítica unamuniana, y su opinión de Darío va de mal en peor. En una conversación con un compañero de letras en 1907 , llega a decir - nunca escribió tal cosa, como maliciosamente han dicho Valle-Inclán y Díaz Plaja entre otros- que a Rubén se le veían las plumas de indio por debajo del sombrero, y su interlocutor - ¿quién sería?hizo que Rubén se enterara de ello. Darío, profundamente herido y quejándose de este ataque tan inesperado como injusto, se mueve a escribir una carta de las más conmovedoras que hemos leído, y que empieza con estas palabras que nos imaginamos leyera Unamuno con escalof ríos:

Ante todo, para una alusión. Es con una pluma que me quito por debajo del sombrero con la que le escribo. Y lo primero que hago es quejarme de no haber recibido su último libro [Poesias]. Podrá haber diferencias entre usted y yo, pero jamás se dirá que no reconozco en usted-sobre todo duespués de haberle leído en estos últimos tiempos-a una de las fuerzas mentales que existen hoy, no en España, sino en el mundo. Mas yo quisiera también de su parte alguna palabra de benevolencia para mis esfuerzos de cultura.

Y después de una alabanza de Unamuno como pensador, como sabio y como poeta, le pide justicia:

La independencia y la severidad de su modo de ser le anuncian para la

24 Ensayos, Vol. III, Obras completas (Madrid, 1950), pág. 771.

25 Ibidem, pág. 776. 
justicia. Sobrio y aislado en su felicidad familiar, debe comprender a los que no tienen tales ventajas. Usted es un espíritu director. Sus preocupa. ciones sobre los asuntos eternos y definitivos le obligan a la justicia y a la bondad. Sea, pues, justo y bueno. ${ }^{26}$

Pocas veces hemos leído palabras tan conmovedoras, tan justas y $\tan$ nobles, palabras que emocionan y entristecen a la vez.

A juzgar por la próxima carta que le escribe Rubén, Unamuno le habría contestado pocos días después, dándole esa justicia y bondad que le pedía, o por lo menos una explicación satisfactoria de sus palabras. Desgraciadamente, esa carta, tan importante para comprender a ambos, se ha perdido. Sin embargo, la explicación incluida en ella le habría satisfecho a Rubén, como dan a entender estas palabras de la segunda carta: "Mucho me satisfizo su gentil carta del 26 del pasado. Creo que con quince días pasados con usted estariamos completamente de acuerdo en todo." 27 De todos modos, si no tenemos esa carta en que se disculpó don Miguel, tenemos un escrito, extraordinario en su fuerza conmovedora también, publicado a la muerte de Dario bajo el título de "Hay que ser justo y bueno, Rubén" y en el cual confiesa públicamente su culpa y su maledicencia. Pero esto lo veremos en el momento oportuno. Por ahora sigamos, cronológicamente, el desarrollo del pensamiento de Unamuno con respecto del noble poeta americano. ${ }^{28}$

En este mismo año de 1907 , tenemos, en una carta al profesor y amigo uruguayo Carlos Vaz Ferreira, otra valoración de la poesía rubeniana en la cual se ve una vez más cuánto mediaba entre ellos en visión artística. Hablando de la rima, dice Unamuno:

Además, la rima establece un elemento de asociación externa de ideas - rima generatrice- buena para quien hace poesía de fuera a dentro. Rubén Darío, verbigracia, necesita de la rima para enlazar y dar coherencia a sus concepciones poéticas, que suelen ser caleidoscópicas y faltas de lazo interior.

20 La carta le llega de París y está fechada el 5 de septiembre de 1907. Véase Epistolario, págs. $38-40$.

27 Ibídem, pág. 40.

28 También llegó a maldecir Rubén, de Unamuno, como nos explica él mismo en su artículo "Unamuno, poeta". En él nos cuenta que "un día, en conversa. ción con literatos, dije de Unamuno: un pelotari en Patmos. Le fueron con el chisme, pero él supo ver la intención, sabiendo que su juego era con las ideas y no con los sentires, y que no es desdeñable encontrarse en el mismo terreno con Juan el vidente." Que sepamos, Unamuno nunca se refirió a este incidente; al contrario, en tan alta estima tenía el artículo de Datio en que nos cuenta este caso que hizo que se imprimiera como prólogo a su libro de poesías Teresa (Madrid, 1924). 
Perdido este hilo caería en impresiones desligadas, en verdadera sarta sin cuerda. Pero a mí la rima me estorba. ${ }^{29}$

Como se ve, el don poético unamuniano no era el rubeniano: un punto más, y de mucho peso también, en que se diferenciaban Rubén y don Miguel.

Aunque Unamuno aparentemente había suavizado su ataque contra Darío, seguía diciendo barbaridades de él en la intimidad y, según las declaraciones que hace en una carta dirigida a Ricardo Rojas el 27 de marzo de 1908 , se ve que todavía no había leído - parece mentira- la producción sólida y fuerte de Rubén. Sus palabras, que ahora transcribimos, tienen que ser basadas en sus primeras poesías; de otro modo no se explica su contenido.

Cuando nos veamos - le escribe- hablaremos de él, a ver si al fin es usted quien me convence de que hay poesía en las caramilladas artificiosas del nicaragüense. Yo no lo culpo de lo que otros, sino que sus versos me parecen terriblemente prosaicos en el fondo, sin pasión ni calor, puras virtuosidades y tecniquerías. Escribe, además, cosas imposibles por la manía de la rima rica. Puesto que hablamos de un príncipe rubio, tenemos que hacerle navegar por el Danubio, así como Bretón de los Herreros saca al obispo de Sigüenza para que nos convenza: 30

Lo cual es muy atinado en cuanto a los poemas de $A z u l$ o las Prosas pro. fanas u otras de semejante contextura. Pero también había publicado Rubén sus Cantos de vida y espliranza (I905) y El canto ervante (1907), libros a los cuales no cuadra esta crítica.

Efectivamente, cuando el mismo Rojas lo visitó en Salamanca el verano del mismo año, se encontró con que Unamuno "no conocía sino algunos versos ultramodernistas del tiempo de Prosas profanas, y yo lo contradije con Cantos de vida y esperanza, mostrándole la sobriedad clásica y la hondura humana de los nocturnos y de ciertos poemas especialmente elegidos por mí con el propósito de impresionar la sensibilidad de Unamuno." Y la impresionó, aunque creemos nosotros que siempre estuvo atenta a las notas rubenianas, a pesar de sus muchas protestas. El mucho protestar - lo ha dicho Unamuno mismo en un lugar-indica cierta atracción hacia lo que se está rebatiendo. Al separarse Rojas y

29 Citado por M. García Blanco, obra cit., pág. 120.

30 Ricardo Rojas, Retablo español (Buenos Aires, 1948), pág. 291. 
Unamuno, le dijo éste a Julio Nombela Campos, catedrático de la universidad que les había acompañado en sus paseos y conversaciones: “ Es listo ese Rojas! ¿Vio usted con lo que me salió para defender a Darío? Quizá tenga razón ..."31 Es más, sabía que tenía razón, pero todavía se negaba a aceptarla.

Lo curioso es que este mismo Rojas se encontró en una situación análoga cuando después fue a visitar a Rubén, y es que vio que Darío negaba a Unamuno de la misma manera que éste negaba a aquél. $Y$ tuvo que "realizar con Rubén esfuerzo análogo para convencerle de que Unamuno era no sólo un pensador extraordinario sino también un gran poe. ta."32 Y Darío reconocía, aunque se negaba a confesarlo, el valor de Unamuno.

Hasta este año - rgo8-ambos, Unamuno y Dario, habian permanecido inmóviles en sus opiniones negativas, pero ahora empiezan por fin a comprenderse y estimarse mutuamente y como debían haberlo hecho desde el principio. En r9o9, publica Rubén su artículo "Unamuno, poeta" en La Nación, estudio que le abrió el camino de la fama en la poesía; en las cartas - las últimas que escribieron-cambiadas entre ellos, hay muchos votos de amistad y de comprensión mutua. En una carta de Unamuno, hasta encontramos que le brindó a Darío una de sus poesías, la intitulada "La viajera", poesía inspirada en un artículo de Rubén sobre la muerte en Barcelona de un poeta costarricense. ${ }^{33}$ En I9ro, Unamuno llega a llamarlo "excelso poeta", a pesar de seguir insistiendo sobre lo mismo: su afrancesamiento:

A eso que llaman el arte por el arte, a todo ese arte lilial, principesco o como se le quiera llamar, lo que le falta es pasión. Acaso a Rubén Dario, para ser aún más excelso poeta que es, para llegar a ser el genio lírico de los pueblos de lengua española, le ha faltado pasión, entusiasmos políticos o religiosos, un fanatismo de cualquier clase; la flaqueza del hombre social en él ha perjudicado al poeta. Su exceso de cosmopolitismo le ha impedido hacerse más universal... Si Darío no ha sentido su Nicaragua, ¿cómo iba a sentir Versalles? Y, a pesar de esto, es un excelso poeta. ${ }^{34}$

No se vuelve a oír la voz de Unamuno hasta la muerte de Rubén en

\footnotetext{
31 Ibidem.

32 Ibidem.

3a Este poema no figura en ningún libro del autor. Lo ha incluido M. García Blanco en su libro ya citado en la página 392.

34 M. García Blanco, articulo cit., pág. 117.
} 
I9I6, cuando escribe el artículo a que hemos aludido antes, "Hay que ser justo y bueno, Rubén", artículo comparable en su nobleza y en su dignidad de hombre a la carta de Darío que lo inspiró. Empieza citando lo principal de la carta de r907, y después nos dice:

Han pasado más de ocho años de esto; muchas veces esas palabras de noble y triste reproche del pobre Rubén me han sonado dentro del alma, y ahora parece que las oigo salir de su enterramiento, aun mollar. ¿Fui con él justo y bueno? No me atrevo a decir que sí. Quería alguna palabra de benevolencia para sus esfuerzos de cultura de parte de aquellos con quienes se creía, por encima de diferencias mentales, hermanado en una obra común. Era justo y bueno su deseo. Y yo, arando solo mi campo, desdeñoso en el que creía mi espléndido aislamiento, meditando nuevos desdenes, seguí ca llándome ante su obra. ¿Fue esto justo y bueno? No me atrevo a decir que sí.35

$Y$ en este tono de remordimiento y recriminación de sí mismo, y con el mismo estribillo desgarrador de "Hay que ser justo y bueno", el artículo sigue. Habla de la obra poética de su amigo y hace una distinción muy justa entre lo hondo y eterno de sus versos de menos fama y lo puramente superficial y exteriorizado de los ultramodernistas:

Le acongojaban las eternas e intimas inquietudes del espíritu y ellas le inspiraron sus más profundos, sus más íntimos, sus mejores poemas. No esas guitarradas que se suele citar cuando de su poesía se habla, eso de "la prin. cesa está triste; ¿qué tendrá la princesa?' o lo del 'ala aleve del leve abanico', que no pasan de leves cosquilleos a una frívola sensualidad acústica; versos de salón sin intensidad ninguna. 36

Sabe distinguir don Miguel; sabe cuando habla el Darío versallesco, el experimentador y el renovador, el menos puro y el más formal, y sabe cuando se le sale del alma su espíritu indígena de indio ameri. cano, cuando Darío, sintiendo su casta la hace vibrar tensamente en sus versos:

Al indio - lo digo sin asomo de ironía, más bien con pleno acento de reverencia-, al indio que temblaba con todo su ser, como el follaje de un árbol azotado por el cierzo, ante el misterio. Pues para él era el mundo en que erró, peregrino de una felicidad imposible, un mundo misterioso. ${ }^{\mathbf{3 7}}$

35 "Hay que ser justo y bueno, Rubén", artícula recogido por González Ol medilla, La ofrenda de España a Rubén Dario (Madrid, 1916), págs. 27-28.

36 Ibidem, pág. 29.

37 Ibídem, pág. 30 . 
Intuía don Miguel esa indianidad en su poesía, y la intuía a despecho del afrancesamiento que se ve a cada paso en ella, y tal vez iba implícito en su frase de que por debajo del sombrero del nicaragüense se le veían las plumas del indio. Más adelante en este mismo artículo le llama en una exclamación apasionadísima "iaquella suprema flor de la indianidad!"

$\mathrm{Y}$ vuelve a recriminarse acongojadamente:

'Sea justo y bueno.' Esto me decía Rubén cuando yo me embozaba arrogante en la capa de desdén de mi silencioso aislamiento, de mi aislado silencio. Y

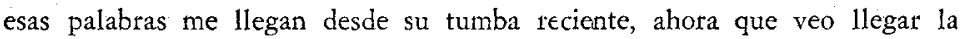
otra soledad, la de la cosecha. ¡No, ni fui justo ni bueno con Rubén; no lo fui! No lo he sido acaso con otros. Y él, Rubén, era justo y era bueno. ${ }^{38}$

$\mathrm{Y}$ en este mismo estudio da a entender don Miguel que la lira de Dario le había gustado desde el principio, pero que se negó a comentar y a aplaudirla, porque no podía:

Nadie como él nos tocó en ciertas fibras; nadie como él sutilizó nuestra comprensión poética. Su canto fue como el de la alondra; nos obligó a mirar a un cielo más ancho, por encima de las tapias del jardín patrio en que cantaban, en la enramada, los ruiseñores indígenas. Su canto nos fue un nuevo horizonte, pero no un horizonte para la vista, sino para el oído. Fue como si oyésemos voces misteriosas que venían de más allá de donde a nuestros ojos se juntan el cielo con la tierra, de lo perdido tras la última lontananza. $Y$ yo, oyendo aquel canto, me callé. $Y$ me callé porque tenía que cantar, es decir, que gritar acaso, mis propias congojas, y gritarlas como bajo tierra, en soterraño. $\mathrm{Y}$, para mejor ensayarme, me soterré donde no oyera a los demás. ${ }^{39}$

Termina este artículo - confesión con unas palabras de los más sin. ceras y honradas que ha escrito:

¡Pobre Rubén! ¿Te llegarán tarde estas líneas de tu amigo que no quiere ser ni injusto ni malo? Nunca llegan tarde las palabras buenas ... ¿Por qué, en vida tuya, amigo, me callé tanto? ¿Qué sé yo!... Qué sé yo!... Es decir, no quiero saberlo. No quiero penetrar en ciertos tristes rincones de nuestro espiritu. Sí, buen Rubén, óptimo poeta y mejor hombre: éste tu huraño y hermético amigo, que debe ser justo y debe ser bueno contigo y con los demás, te debía palabras, no de benevolencia, de admiración y de fervorosa

38 Ibídem.

30 Ibidem, págs. 32-33. 
alabanza, por tus esfuerzos de cultura. Y si Dios me da salud, tiempo y ánimo, he de decir de tu obra lo que -más vale no pensar en por quéno dije cuando podías oírlo. ¿Lo oirás ahora? Quisiera creer que sí. Hay que ser justo y bueno, Rubén. 40

No hemos querido comentar estas palabras por juzgarlas incomentables. Hablar de ellas sería quitarles valor y estropearles su belleza. Pocas veces hemos leído - no sólo en Unamuno sino en cualquier otro poeta- palabras de más desgarradora confesión. Quedará para siempre como supremo monumento a un poeta de igual supremacía.

En verdad, el estudio anunciado al final del artículo nunca se hizo, sencillamente porque ya estaba escrito. Sin embargo, en años venideros iba a volver a exaltarle como poeta y como amigo, y a expresar repetidas veces su remordimiento de no haber hablado de él mientras vivía. Así, por ejemplo, en octubre de este mismo año de r9r6, cuando, en un viaje a la Cartuja de Valldemosa, un retito mallorquín, se hospeda en casa de don Juan Sureda, la misma en que pasó Darío una temporada de sus últimos años, recuerda cariñosamente a su amigo y, profundamente dolido, escribe estas líneas:

Allí el pobre Rubén se refugió, maltrecho y ya definitivamente vencido por el diablo amarillo, a emprender la última lucha, la desesperada. Allí escribió algunos de sus últimos cantos, entre ellos el de la cartuja, después de haber leído una vida de San Bruno... La cartuja de Valldemosa está henchida de recuerdos del pobre Rubén y yo sentía el remordimiento de lo que pude haberle dicho y esperó él que le dijese - me consta-y no lo dije, cuando cada día, mañana y noche, pasaba por el cuarto en que el pobre forcejeó espiritualmente contra la nube que le iba ciñendo y ahogando el alma. ${ }^{41}$

Todavía tenía demasiada vívida en su mente la muerte de Rubén para poder escribir sobre el valor literario de su poesía. El recuerdo aquí es de remordimiento y de honda compasión. No podía haber escrito de otra manera.

Cuatro años después, en I920, escribe don Miguel el prólogo al li. bro de poesías de Amado Nervo, En voz baja, y al hablar de la indianidad de éste, vuelve a sentir al Darío indio, el mismo de quien habló en I9I6.

40 Ibídem, págs. 33-34.

41 Andanzas y visiones españolas, Vol. I, Obras completas (Madrid, 1950), págs. $680-681$. 


\begin{abstract}
¿Por qué hay algunos americanos que se encabritan y revuelven contra esa castiza y hermosa denominación de Indias occidentales? ¿Por qué contra eso de que se llamara indianos a los americanos?... Pero ¿no es América, y sobre todo su litoral del Pacífico, cuyo susurro oyeron en su niñez, desde León el uno, desde Tepic el otro, Darío y Nervo, un Oriente del Extremo Oriente asiático? ¿ $Y$ es que las almas de los primitivos de México y de Nicaragua no tenían alguna hermandad con las de los asiáticos del Extremo Oriente? ¿No hay sabiduría india en aquéllos? ${ }^{42}$
\end{abstract}

Sí, la hay, y cuanto más se mira en su poesía más se le descubre $\epsilon 1$ alma indiana y más se le siente latir la sangre india que corría por sus venas. Y no nos referimos a sus poemas, como "Caupolicán", que tratan de lo indio expresa y directamente, sino los en que la visión estética -sus Salmos, por ejemplo- ante el mundo parece ser de una pasividad, de una melancolia y de una sobriedad verdaderamente nativas americanas, indianas. Aun en los poemas ultramodernistas, ¿no se ve acaso por debajo del afrancesamiento cierto sentido y cierta estética venidos de lo indiano? En un poema como "Sonatina", verbigracia, ¿no se ve por debajo de los versos ondulantes, de "hamaca", un sentimiento patrio, y por debajo de la rima riquísima una sobriedad paralela a la de sus antepasados? Nosotros, por lo menos, creemos intuirlo como Unamuno lo intuía también. Tenía miga - estamos convencidos de ello- aquella frase de don Miguel de que se veían plumas indias por debajo del sombrero de Darío, y no creemos que la pronunciara sólo para hablar mal de su poesía.

Lo que nunca aceptó Unamuno -iría contra su propia visión y expresión artística-era lo que él denominaba el escribir "versos a ojo", y así hacer tónicas - para conservar la rima, claro - palabras que en" rigor no lo son. En este punto no creemos que haya disentimiento alguno con don Miguel, ya que, por ejemplo, el "si" condicional, palabra átona proclítica, no puede rimar con "ti", pronombre tónico; ni se pueden rimar la proposición "de" y "té", verbigracia. Y Rubén a veces versificaba a ojo y caía en la trampa, a pesar de ser un poeta de tan alta categoría. "Como a ojo están hechos versos de Rubén Darío, de Manuel Machado y de otros excelentes versificadores - estos dos, además, grandes poetas- que se han empeñado en hacer tónicas palabras -conjunciones y preposiciones y algún pronombre-que son, incluso en sus bocas, átonos. Rimar el pronombre indefinido 'una' con 'luna' suele ser un disparate." 43 Aunque la críti-

42 "Prólogo" a Amado Nervo, En voz baja, Vol. VII, Obras completas (Madrid, 1920), pág. 22.

43 "Versos a ojo", Vol. V, Obras completas (Madrid, 1950), págs. 372-373. 
ca es de poco peso, vale que la miremos bien, porque así se ve el cuidado y la atención con que leía la poesía de Darío. Si la hubiera leído, como dejó escrito, como poesía de poco valor, no le habría captado estas íntimas peculiaridades.

Por esta fecha - r920 - la estrella modernista ya está apagada, y don Miguel, grandemente aliviado, puede mirar hacia atrás y valorar de nuevo, serena y objetivamente, algunas de sus opiniones antimodernistas más cortantes, para darles más vigor y vigencia. En su serie de artículos "Alrededor del estilo", publicados a lo largo de I924 en la revista madri. leña El Imparcial, habla del modernismo, la influencia de Remy de Gourmont en autores hispánicos y el afrancesamiento de Rubén Darío. Dice:

A Remy de Gourmont, que dijo muchas más tonterías sobre el español que sobre otra cosa cualquiera, le hicieron creer los americanos de lengua española... que los americanos han desanquilosado la longua española. No supo que Rubén Darío no ha hecho sino volver a Góngora, y que la lengua de Rubén Darío es la menos afrancesada, en el fondo, que cabe, que es una lengua hondamente castiza. $Y$ si nuestros casticistas no lo creen así, es porque nada hay menos castizo que un casticista. Lo único que Rubén evitaba eta cierto hipérbaton, ciertas trasposiciones que la plenitud de nuestra flexión permite. Un crítico americano decía que Rubén no habria escrito 'de tu balcón las tapias a escalat', por ejemplo; pero, ¿y qué?44

¡Cómo ha cambiado don Miguel desde los años en que hablaba de guitarradas y caramilladas poéticas! Pero, no olvidemos que nunca - como hemos tratado de mostrat- se dijo esas cosas a su corazón, mejor, a su propia sensibilidad de poeta. Desde que le leyó por primera vez - recuérdese la carta a Ruiz Contreras de principios de r899- sabía Unamuno que Rubén estaba destinado a conquistar con su lita al gran mundo de habla española. Lo sabía, repetimos, aunque rehusó confesárselo. Había empezado mal en su tratamiento de Darío, pero en vez de confesar su culpa y así romper esa muralla helada que los separaba mientras Rubén vivía, persistió en el empeño de defender su error. Era como si Unamuno estuviera siguiendo al pie de la letra el famoso consejo que Diego Láinez, al yacer moribundo, le dio al Cid campeador, consejo admirablemente presentado en esta redondilla de Guillén de Castro, y que tanto gustaba de repetir Unamuno: "Tratar siempre de acertalla, /la honrada y principal,/ pero si la acierta mal,/ defendella y no enmendalla." 769.

44 Alrededor del estilo, Vol. 1, Obras completas (Madrid, 1950), págs. 768- 
Para terminar nuestra exposición cronológica del desarrollo de la crítica unamuniana sobre la poesía de Rubén Darío, queremos ahora citar dos poemitas extraordinarios que incluye aquél en su Cancionetro, disario poético. El primero, el número 275 , es una defensa elocuentísima de lo castizo hispánico del verso y del lenguaje de Rubén:

$$
\begin{aligned}
& \text { 'Mágico pájaro regio' } \\
& \text { que Rubén en castellano } \\
& \text { dijo, y no dijo en francés, } \\
& \text { con su erre y con sus ges, } \\
& \text { esdrújulo americano, } \\
& \text { en Nicaragua un arpegio. }{ }^{45}
\end{aligned}
$$

Como se sabe, don Miguel se pasó la vida experimentando con su propia expresión poética, ensayando toda clase de ritmos, rimas y estructuraciones métricas. Y en el Cancionero, hasta se mete con el eneasilabo, verso cuyo ritmo se le escapaba y que Rubén había elevado a un prestigio en que nunca se había tenido antes. ¿Estaría pensando en su amigo fallecido cuando compuso estos en sí admirables eneasílabos politrítmicos?

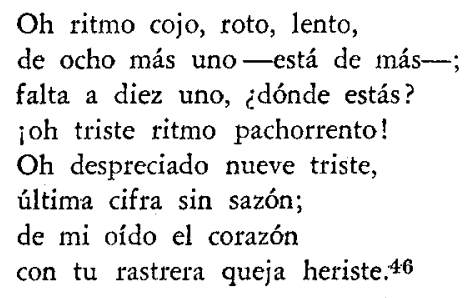

Estamos dispuestos a creer que sí.

\section{PhILIP METZIDAKIS}

Univensidad de Yale, New Hatien, Connecticut. 
